\title{
Fuelwood Use and Carbon Emission Reduction of Improved Biomass Cook Stoves; Evidence From Kitchen Performance Test in Tigray, Ethiopia
}

\section{Ashenafi Manaye ( $\square$ manayeashenafi@yahoo.com)}

Tigray Institute of Policy Studies (TIPS), Mekelle, Ethiopia https://orcid.org/0000-0003-3314-9744

\section{Selemawit Amaha}

Ethiopian Environments, Forest and Climate Change Commission (MoEFCCC), Addis Ababa, Ethiopia.

\section{Yirga Gufi}

Mekelle Environments and Forest Research Center, Mekelle Ethiopia

\section{Berihu Tesfamariam}

Mekelle Environments and Forest Research Center, Mekelle Ethiopia

\section{Adefires Worku}

Ethiopian Environments, Forest and Climate Change Commission (MoEFCCC), Addis Ababa, Ethiopia.

Haftu Abrha

Institutes of Climate and Society, Mekelle University, Mekelle, Ethiopia

\section{Original article}

Keywords: Fuelwood, Improved cooking stove, Kitchen performance test, "Mirt" stove, "Tikikil" Stove

Posted Date: August 12th, 2020

DOI: https://doi.org/10.21203/rs.3.rs-55546/v1

License: @ (i) This work is licensed under a Creative Commons Attribution 4.0 International License. Read Full License 


\section{Abstract}

\section{Background}

In Ethiopia, biomass is the main form of fuel approximately for $92 \%$ of the population. Currently, several strategies were designed to reduce fuelwood consumption and greenhouse gases (GHG) emission by implementing improved cooking stoves (ICS). Nevertheless, the adoption of ICSs has been very slow. Therefore, these studies were conducted to assess the performance of ICS ("Mirt" and Tikikil") on fuelwood consumption and greenhouse gas emission (GHG) in the kitchens of real households.

\section{Methods}

To select the study households $(\mathrm{HH})$, both cross-sectional and longitudinal study designs were used. We used Kitchen Performance Test (KPT), based on three days of repeated fuel wood use measurements to compare the wood-saving performance of ICS and the traditional cook stoves (TCS). The carbon emission in the study area was calculated based on the clean development mechanism and United Nation's Framework of Convention on Climate change.

\section{Result}

The study indicated that there were significant differences $(p<0.05)$ between the use of improved and traditional cooking stoves in total and per capita wood consumption. The use of "Mirt" and "Tikikil" than the traditional stove reduced the household wood consumption by $35 \%$ (438 kg/ year) and 18\% (185 kg/ year), respectively. Likewise, use of these ICS stoves lead to decrease of 0.65 and 0.27 tons of carbon dioxide equivalents $\left(\mathrm{CO}_{2} \mathrm{e}\right)$ per stove per year.

\section{Conclusion}

Adopting of ICS reduced the amount of fuelwood used and carbon emission at household level significantly as compared to the use of TCS. This finding have implication on adoption of ICS technology is important on reducing $\mathrm{CO}_{2}$ emission, forest degradation and household workloads.

\section{Introduction}

Worldwide around 1.6 billion people depend on forest resources for fuel, food, water, medicines, traditional cultures and livelihoods [1]. More than $40 \%$ of the world's population depends on the biomass as their primary cooking fuel [2-4], of which approximately $90 \%$ live in sub-Saharan Africa, still depend on traditional biomass energy [5,6]. On 2040 Diefenderfer et al. [7] reports that, 1.8 billion people will remain reliant on traditional biomass energy as a cooking fuel, with the overwhelming majority living in Sub-Saharan Africa (SSA).

In Africa, in spite of the availability of various energy sources, more than $80 \%$ of the total population in most countries is still using traditional biomass as the main source of energy for cooking [7]. Currently, several strategies were designed to reduce fuel wood consumption and GHGs emission by implementing improved cookstoves (ICS), increasing efficient fuel use and changing the cooking behaviors [8-11]. Although in sub-Saharan Africa and the Least Developed Countries, only $7 \%$ of people who rely on solid fuels use improved cook-stoves [12]. In Ethiopia also, biomass is the main form of fuel for approximately for $92 \%$ of the population [13,14].

The rate of deforestation and forest degradation resulting carbon dioxide emission to the atmosphere are still immense [15]. Assess to fuelwood is one of the major anthropogenic activities resulting in land degradation and causing significant negative impact on the forest $[5,16]$. Approximately $1-2.4 \mathrm{Gt} \mathrm{CO}_{2}$ e of $\mathrm{GHGs}$ are emitted annually in the production and use of fuelwood and charcoal, which is $2-7 \%$ of the global anthropogenic emissions [17]. Due to the dependency on biomass, the $\mathrm{CO}_{2}$ emission in Ethiopia has increased from 5.1 million tons in 2005 to 6.5 million tons in 2010 [14].

The national improved cook stove program of Ethiopia aims to support the distribution of 9 million ICS by 2018. The long-term goal is to disseminate 31 million stoves before 2030 [18]. These program introduced an active ICS production and sales sector with current annual sales of approximately 66,000 injera ICS (Mirte) and 16,000 rocket-type ICS woodstoves (Tikikil) [19].

The main reason for introducing ICS was to reduce forest degradation [8,16, 20-21], reduce indoor and outdoor pollution[10,22], improve the quality of health [23-25], improve the socioeconomic benefit Onyeneke et al. [26] and reduce the GHGs emission [14,16]. However, the adoption of ICSs has been still very slow [27]. The adoption rate of ICS technology in developing countries depends on the 
socio-cultural settings [27-29]. The GHGs emission from the burning wood also depends on various factors such as kitchen characteristics, stove characteristics, type of fuel, quantity of fuel, method of cooking and time-activity profile of the household [22]. For instance, in the study site, the staple food items called "Injera" baking consumes over $60 \%$ of the entire household cooking fuel [30].

Despite the fact ICSs are better option than the traditional stove; there is little empirical evidence on fuel use performance and GHG emission of improved wood stoves [2, 8]. The performance of wood stove in fuel reduction was mainly assessed using experimental methods such as water boiling test and controlled cooking test [2]. While, the most representative method is KPT, a stove performance test that quantifies fuelwood used in the household under the actual use [2,31]. Nowadays, very few studies have been published with this method [2,32]. Therefore, the objective of the present study was to assess the performance of improved ("Mirt" and "Tikikil") and traditional cook stove on fuelwood consumption and climate change mitigation in the kitchens of real households using KPT methods.

\section{Methodology}

\subsection{Study area}

The study was conducted in Asgede Tsimbla district, northern Ethiopia located at about 900-1800 m.a.s.l. with an estimated area of $2,358 \mathrm{~km}^{2}$ (Figure1). The rainfall of the area is bimodal with a short rainy season occurring between January and April, and a long rainy season from June to August. Average annual rainfall is about $550-900 \mathrm{~mm}$. The mean maximum temperature ranges between $20^{\circ} \mathrm{C}$ (November and December) and $35^{\circ} \mathrm{C}$ (January and March). The district has a total of 29,874 households $(23,618$ males and 6,256 females) with a total livestock population of $135,661(33)$.

\subsection{Sampling methods}

To select the study villages, first discussion was done at regional and district energy offices. Two potential kebeles (Lemlem and Hitsats) using both improved and traditional biomass-based stoves from Asgede Tsimbla district was selected (Figure 1). Lemlem kebele were selected because most of the improved baking stoves locally called "Mirt" user is found in this village. This stove is distributed by the World Vision. The second Hitsats keble is selected because the use improved cook stove locally called "Tikikil" which is distributed by Zoa Relief projects.

To select the study households $(\mathrm{HH})$, we used both cross-sectional and longitudinal methods. In Lemlem keble because of the absence of both improved and traditional stove users, cross-sectional methods are taken. During the selection of households, both socioeconomic and environmental factors which can affect the sampling are considered. While in Hitsas households agreed to use both the improved and traditional cook stoves (TCS) were selected. In this study a total of 192 households were participated. The number of household covered on this study were more than the rule of thumb (10\% of the total number of ICS users) suggested on KPT protocol [34]. Of which, $43 \mathrm{HHs}$ each from improved baking stove ("Tikikil”) and traditional baking stove (TBS) users; and 53 were both improved and TCS users.

\subsection{Description of both improved and traditional cookstoves}

The improved stoves called Mirt and Tikili had specified materials and dimensions when first designed in Ministry of water and energy of Ethiopia and GIZ in 2011 [35]. Whereas, the traditional cooking stove were made up of stone and mud and have not fixed structure and design (Figure 2)

Mirt stove is produced with mortar using a mixture of scoria (red ash) or pumice or river sand with cement for the service more than five years. It is used for baking of the staple food items called "Injera" and/or bread. The stove has six parts that are joined together, four parts fit to make a cylindrically shaped enclosure and two other parts joined one on top of the other and are fitted with the cylindrical enclosure from behind (Figure 3). The two parts serve as smoke outlet and rest for the cooking pot. There is classic Mirt stove- with $6 \mathrm{~cm}$ and the slim mirt stove with $4 \mathrm{~cm}$ of wall thicknesses. Depending on the thickness of the parts as well as the raw materials used, the total weight of Mirt stove ranges from $45 \mathrm{~kg}-65 \mathrm{~kg}$. Mirt stove dimensions for cylindrical enclosure is: diameter: $64-70 \mathrm{~cm}$, height: $22-24 \mathrm{~cm}$, fuel/air inlet: $24 \mathrm{~cm}$ by $11 \mathrm{~cm}$, and smoke outlet: $19 \mathrm{~cm}$ by $7 \mathrm{~cm}$ and for rear parts is: $32 \mathrm{~cm}$ wide, $26 \mathrm{~cm}$ deep and $35 \mathrm{~cm}$ high.

Page $3 / 11$ 
"Tikikil" is basically a rocket stove, however adopted to suit the conditions in most Ethiopian households and local production techniques; meaning "Appropriate". Tikikil" is adopted to replace the most inefficient but widely used traditional three-stone stove (Open Fire). The design parameters were considered the households' pot sizes, ease of production, affordability, use of locally available raw materials and skills. It is designed to accommodate pot sizes of $25 \mathrm{~cm}$ (and smaller) in diameter. The stove has two main parts which include the ceramic liner and the metal part (Figure 3). The metal part contains of the sheet metal cladding and the wood support. This stove is used to prepare sauce (commonly known "Wot"), boiling water, making coffee and similar activities involve burning a fuel several times a day.

\subsection{Fuelwood use measurement}

Our KPT were based on three days of repeated fuel wood use measurements in a relatively enough sample size, thereby limiting the influence of inter-household variability. According to the experimental protocol, participants prepared three patches of wood enough for three days of cooking, based on their typical fuel requirement. The participants didn't provide with wood as this can bias the test result [34]. On the $1^{\text {st }}$ day of the tests, the three batches of wood were weighted using pocket balance and recorded. The wood moisture content was measured using pin-type electorophysics moisture meter (MT800). For moisture content, three pieces of wood samples from the stock were taken randomly and measured using moisture meter at the top, middle and bottom parts. On the $2^{\text {nd }}$ day of the test, the wood that remained from the first day was weighted, and the difference recorded as the day's fuel. The moisture content of the randomly selected three pieces of wood was also measured. The same procedure was repeated on the day three. The adult equivalent for meals in a household was also calculated for each baking days.

The probable impact of fuel savings by using ICS on carbon emission in the study area was calculated based on the clean development mechanism and United Nation's Framework of Convention on Climate change [36]; Table1)

E= Fuelwood saved X f NRB X NCV X EF Eq. (1)

Where:

$E=$ emissions; $\mathrm{fNRB}=$ fraction of non-renewable biomass; $\mathrm{NCV}=$ net calorific value (for wet wood); $\mathrm{EF}=$ default emission factor (per unit of energy)

\subsection{Statistical analysis}

An excel software based tool developed by Shell Foundation was used to calculate the daily fuel and energy consumption by a household. Here, daily refer to the sessional baking or cooking day, because the firewood consumption was not measured daily. Independent sample t test was used to compare the consumption rate of wood and energy when households were using improved cook stove and traditional ones. Analysis of variance was used to know whether there is significant difference in the consumption of wood, energy and emission reduction by using the two different cook stoves. The social data were encoded in SPSS software, and descriptive results were produced for interpretation and description.

\section{Results}

\subsection{Description of the study household and participants}

Independent t-test analysis showed that there was no significant difference $(p>0.05)$ in number of individuals in all age categories between Mirt and TBS. On average, these selected HHs used Mirt stove for more than 2 years (Table 2). Whereas, Tikikil stove is recently distributed (Mean age of 7 months). The average family size between traditional and improved baking stove is insignificant (Independent $\mathrm{t}$-test; $\mathrm{t}=-1.060 ; \mathrm{df}=84 ; \mathrm{P}>0.05$ ). 


\subsection{Average wood consumption}

The entire surveyed households only used fuelwood for baking "injera", to cook "Wet" and heat water. Charcoal may be used to prepare coffee but the charcoal was produced from the burnet wood. Majority of households collected firewood from their backyard resource, only a small proportion bought from the market. The dominant dry woody species used for firewood is Ziziphus spina-christi (33\%) followed by Ficus sycomorus (22), Cordia Africana (19\%), Acacia Sps. (16\%) and others (10\%).

The study shows that there is significant difference $(p<0.05)$ between the use of Mirt and TBS in total and per capita wet and dry wood used. The use of "Mirt" reduced the household dry wood consumption by $34 \%$ over the TBS (Table 3). Household with improved Mirt stove consumed $2.34 \mathrm{~kg}$ per session $(95 \% \mathrm{Cl}: 1.78,3.61)$ less than household with traditional baking stove users. The annual household's consumption of Mirt stove users were $242 \mathrm{~kg}$ of fuelwood per person per year which is $24 \%$ less than the traditional baking stoves.

Similar to improved baking stove, there is significant difference $(p<0.05)$ between the improved and traditional cooking stove in total and per capita wood consumption. Use of Tikikil reduced the household dry wood consumption by $18 \%$ (Table 4).

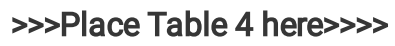

\subsection{Valuation of carbon reductions from improved stoves}

The total $\mathrm{CO}_{2}$ emission reduction per stove per year was significantly different between the traditional and improved stoves (Figure 4). The Mirt stove saves $34 \%$ of fuelwood in the field or $438 \mathrm{~kg}$ per household per year. The conversion of fuelwood to $\mathrm{CO}_{2}$ emission reductions showed that, fully adopted Mirt stove will lead to decrease by 0.70 tons of $\mathrm{CO}_{2}$ per stove per year. The emission footprint (tone $\mathrm{CO}_{2}$ per capita) of "Mirt" adopters $0.39 \pm 0.27$ tone $\mathrm{CO}_{2}$ per year $(95 \% \mathrm{Cl}: 0.30,0.47$ ) were significantly lower (Independent $\mathrm{t}$-test; $\mathrm{t}$ $=2.053 ; \mathrm{df}=84 ; 5 \mathrm{p}<0.05)$ compared to the traditional baking stove users.

The results of our empirical study show that each "Tikikil" user leads to average fuelwood savings of $185 \mathrm{~kg}$ per year. The amount of $\mathrm{CO}_{2}$ e emission reduction per year using TCS is significantly higher than that of ICS (Tikikil) users (Independent $\mathrm{t}$-test; $\mathrm{t}=3.376$; $\mathrm{df}=$ $100 ; P<0.05)$. Assuming a net calorific value of $15 \mathrm{MJ} / \mathrm{kg}$, Fraction of non-renewable biomass of $88 \%$ and an emission factor of $112 \mathrm{~g}$ of $\mathrm{CO}_{2}$ per $\mathrm{MJ}$ of fuelwood (Table 1), this corresponds to 0.296 tons of $\mathrm{CO}_{2}$ per ICS per year (Figure 4).

\section{Discussion}

In Ethiopia Injera baking is the most energy-intensive activity, accounting for over $50 \%$ of all primary energy consumption in the country, and over $75 \%$ of the total energy consumed in households $[13,16]$. In this study, the average amount of fuelwood consumed for baking injera per session was higher than study conducted in the southern Ethiopia, Bale Eco-Region of Ethiopia and south western part of Ethiopia [16, 36-37]. This was due to "Injera" is common traditional food in the study area than the southern and south western part of Ethiopia. Based on laboratory test, Mirt stove has a $50 \%$ wood fuel saving as compared to the 3-stone stove, reflecting how lab and field conditions can differ [34,38]. Whereas, the percentage of our improved baking stove saved fuelwood (34\%) comparable with study conducted in Gonzie stove (33.8-54\%), while smaller than study conducted in Mirt stove (47.8\%) in Southern Ethiopia Fekadu et al. [37] , in Mirt stove of South western Ethiopia (38.9\%) Dresen et al. [16] and higher than the study conducted by Gebreegziabher et al. [3] in four regions of Ethiopia (22-31\%), Gizachew and Tolera [38] study conducted in Bale Eco-Region of Ethiopia (29\%) . Beside to the fuel type, meal types and location specific characteristics, differences were due to variation in the use of traditional baking stove (control). i.e., our study traditional stoves (Fig 2c) were relatively improved than the others two studies traditional stove (which is three stone). We observed that ICS were used for cooking (e.g. wot) and boiling water activities through its chimney (Fig. 2c). Dresen et al. [16], showed that an additional fuelwood saving of about $9 \%$ can be achieved from the boiling and cooking activities that can be done simultaneously with baking injera. The use of more energy in the ICS than the traditional stove confirms the study conducted in laboratory [34]. The $436 \mathrm{~kg}$ per year fuelwood saving per household translates to annual wood saving of 28.78 million $\mathrm{kg}$ from the Ethiopian annual sales of approximately 66,000 Mirts [19].

We found that variation in fuelwood use was related to the type of cook stove used, with Tikikil stoves consuming substantially less fuelwood than the traditional cooking stoves. The finding of our studies were consistent with study conducted in rocket mud stove 
program of Kenya Ochieng et al. [2], study in India, Nepal and Peru by Johnson et a., [40], in Southern Ethiopia by Mamuye et al. [8] and study conducted in Iran by Rasoulkhani et al. [4]. The amount of fuelwood saving by Tikikil (18\%) was lower than the study conducted on the laboratory (50\%) but comparable with the study conducted in ICS of Kenya (20-50\%) and within the range of report in the sub Saharan Africa $10 \%$ to $60 \%$ by Zein-Elabdin, [41]. The difference in fuel wood consumption among various studies could be attributed to the difference in design and material from which they made [42]. The design and materials are the most important valuable that affect fuelwood consumption of stoves [8]. For instance, the traditional cooking stoves of our study (Figure 2c) were relatively improved as compared to the other studies traditional three-stone stove. The $187 \mathrm{~kg}$ per year fuelwood saving per household translates to annual wood saving of 2.99 million $\mathrm{kg}$ from the Ethiopian annual sales of approximately 16,000 Tikikil [19].

Beside to the fuelwood reduction, our study reveals that the use of ICS (both cooking and baking stoves) reduced the carbon emission to the atmosphere. Our study were consistent with study conducted in Ethiopia[8, 16, 37,42]. The $\mathrm{CO}_{2}$ emission reduction of our study Mirt stove was within the range of the CRGE strategy documents which is the abatement potential of $0.6-1.4 \mathrm{t} \mathrm{CO}_{2} \mathrm{e} / \mathrm{stove}$ year, depending on the stove type [18]. However, lower than the study conducted by Dissanayake et al. [43] which is 0.94 tons of $\mathrm{CO}_{2}$ saved per household per year but higher than Gizachew \& Tolera [38], which is the reduction of 0.494 tons of $\mathrm{CO}_{2}$ e per ICS user. The amount of $\mathrm{CO}_{2}$ e reduction using Tikikil cooking stove is lower than CRGE strategy report. The difference between controlled tests and performances under real household condition is expected [35,37].

\section{Conclusion}

This study presented results on the fuelwood saving and emission reduction potential of ICS (specifically called Mirt and Tikiki stove), which were disseminated in Tigray regional state, Ethiopia. The results from this specific study site showed that the use of ICS reduced the amount of fuelwood used at household level significantly as compared to the use of TCS. This study revealed that use of ICS in the study area resulted in household annual fuelwood and $\mathrm{CO}_{2}$ emission reduction of about $438 \mathrm{~kg}$ and 0.70 ton of $\mathrm{CO}_{2}$ e from Mirt users, $185 \mathrm{~kg}$ and 0.296 ton of $\mathrm{CO}_{2}$ e from Tikikil stove users. Beyond to the aim of relieve the rural $\mathrm{HHs}$ burden of fuelwood collection and opportunity cost associated with, our study reveals that the use of ICS can be integrated in clean development strategies and reduce forest degradation initiatives mainly in developing countries where biomass plays a major role as an energy source. Seasonal variation and type of fuelwood used is expected based on availability of other sources (e.g. cow dung) and also number and type of meals prepared. Hence, further research to conduct KPT over all seasons to accommodate for seasonal variation in fuelwood use is recommended.

\section{List Of Abbreviations}

$\mathrm{CO}_{2}$ e: Carbon dioxide equivalents; GHG: Greenhouse gases ICS: Improved cook stove; KPT: Kitchen performance test; TCS: Traditional cook stove;

\section{Declarations}

\section{Ethics approval and consent to participate}

Not applicable

\section{Consent for publication}

Not applicable

\section{Availability of data and materials}

All data generated or analyzed during this study can be obtained from the corresponding author.

\section{Competing interests}

The authors declare they have no competing interests.

\section{Funding}


Not applicable.

\section{Authors' contributions}

AM is the lead author and made a substantial contribution to the conception and design of the manuscript; SA, planned the study \& collected data; YG \& BT, data feeding \& editing the manuscript; HA, supporting on data analyzing and editing the manuscript; AW, planned the study and coordinating the project.

\section{Acknowledgements}

We acknowledge the financial support provided by Environment, Forest and Climate Change Commission (EFCCC) for field survey. The first author acknowledges to the logistic and technical support offered from the staff Tigray Region Agency of Mines \& Energy.

\section{Authors' information (optional)}

${ }^{1}$ Tigray Institute of Policy Studies, Mekelle, Ethiopia. ${ }^{2}$ Ethiopian Environments, Forest and Climate Change Commission (MoEFCCC), Addis Ababa, Ethiopia. ${ }^{3}$ Climate science research process, Mekelle Environment and Forest Research Center, EEFRI, Mekelle, Tigray,Ethiopia. ${ }^{4}$ Institute of Climate and Society (ICS), Mekelle University, Mekelle, Ethiopia

\section{References}

1. World Bank (WB) Report. Sustaining forests: a development strategy. Washington; 2004.

2. Ochieng CA, Tonne $\mathrm{C}$, Vardoulakis $\mathrm{S}$. A comparison of fuel use between a low cost, improved wood stove and traditional threestone stove in rural Kenya. Biomass and Bioenergy [Internet]. 2013;58:258-66. Available from: http://dx.doi.org/10.1016/j.biombioe.2013.07.017

3. Gebreegziabher Z, Beyene AD, Bluffstone R, Martinsson P, Mekonnen A, Toman MA. Fuel savings, cooking time and user satisfaction with improved biomass cookstoves: Evidence from controlled cooking tests in Ethiopia. Resour Energy Econ [Internet]. 2018;52:173-85. Available from: http://dx.doi.org/10.1016/j.reseneeco.2018.01.006

4. Rasoulkhani M, Ebrahimi-Nik M, Abbaspour-Fard MH, Rohani A. Comparative evaluation of the performance of an improved biomass cook stove and the traditional stoves of Iran. Sustain Environ Res [Internet]. 2018;28(6):438-43. Available from: https://doi.org/10.1016/j.serj.2018.08.001

5. Koffi CK, Gazull L, Gautier D. Variability of household fuelwood consumption in a rural Sudano-Sahelian context in Burkina Faso. Energy Sustain Dev. 2018;47:75-83.

6. Urmee T, Gyamfi S. A review of improved Cookstove technologies and programs. Renew Sustain Energy Rev. 2014;33:625-35.

7. Diefenderfer J, assumptions Vipin Arora M, Singer LE. International Energy Outlook 2016 Liquid fuels [Internet]. Vol. 0484, Doe/Eia0484. 2016. 202-586 p. Available from: https://www.eia.gov/outlooks/ieo/pdf/0484(2016).pdf

8. Mamuye F, Lemma B, Woldeamanuel T. Emissions and fuel use performance of two improved stoves and determinants of their adoption in Dodola, southeastern Ethiopia. Sustain Environ Res [Internet]. 2018;28(1):32-8. Available from: https://doi.org/10.1016/j.serj.2017.09.003

9. Adkins E, Tyler E, Wang J, Siriri D, Modi V. Field testing and survey evaluation of household biomass cookstoves in rural subSaharan Africa. Energy Sustain Dev [Internet]. 2010;14(3):172-85. Available from: http://dx.doi.org/10.1016/j.esd.2010.07.003

10. Yip F, Christensen B, Sircar K, Naeher L, Bruce N, Pennise D, et al. Assessment of traditional and improved stove use on household air pollution and personal exposures in rural western Kenya. Environ Int [Internet]. 2017;99:185-91. Available from: http://dx.doi.org/10.1016/j.envint.2016.11.015

11. Muralidharan V, Sussan TE, Limaye S, Koehler K, Williams DL, Rule AM, et al. Field testing of alternative cookstove performance in a rural setting of Western India. Int J Environ Res Public Health. 2015;12(2):1773-87.

12. Legros, G., Havet, I., Bruce, N., Bonjour, S., Rijal, K., Takada, M., \& Dora C. the Energy Access Situation in Developing Countries. UNDP WHO New York [Internet]. 2009;(November):142. Available from: http://www.who.int/indoorair/publications/PowerPoint_Energy_Access_paper-Ir.pdf\%0Ahttp://scholar.google.com/scholar? $\mathrm{hl}=$ en\&btnG=Search\&q=intitle:THE+ENERGY+ACCESS+SITUATION+IN+DEVELOPING+COUNTRIES+A+Review+Focusing+on+the\#0 
13. Beyene AD, Koch SF. Clean fuel-saving technology adoption in urban Ethiopia. Energy Econ [Internet]. 2013;36:605-13. Available from: http://dx.doi.org/10.1016/j.eneco.2012.11.003

14. Mondal MAH, Bryan E, Ringler C, Mekonnen D, Rosegrant M. Ethiopian energy status and demand scenarios: Prospects to improve energy efficiency and mitigate GHG emissions. Energy [Internet]. 2018;149:161-72. Available from:

https://doi.org/10.1016/j.energy.2018.02.067

15. Hosonuma N, Herold M, De Sy V, De Fries RS, Brockhaus M, Verchot L, et al. An assessment of deforestation and forest degradation drivers in developing countries. Environ Res Lett. 2012;7(4).

16. Dresen E, DeVries B, Herold M, Verchot L, Müller R. Fuelwood savings and carbon emission reductions by the use of improved cooking stoves in an afromontane forest, Ethiopia. Land. 2014;3(3):1137-57.

17. FAO. the Charcoal the Charcoal. 2017.

18. Federal Democratic Republic of Ethiopia (FDRE). Ethiopia's Climate-Resilient Green Economy. Addis Ababa, Ethiopia; 2011.

19. Economics Vivid. Results-based financing in the energy sector: an analytical guide [Internet]. 2014. Available from: https://www.vivideconomics.com/

20. Singh G, Rawat GS, Verma D. Comparative study of fuelwood consumption by villagers and seasonal "Dhaba owners" in the tourist affected regions of Garhwal Himalaya, India. Energy Policy. 2010;38(4):1895-9.

21. Teka K, Welday Y, Haftu M. Analysis of household's energy consumption, forest degradation and plantation requirements in Eastern Tigray, Northern Ethiopia. Afr J Ecol. 2018;56(3):499-506.

22. Sharma D, Jain S. Impact of intervention of biomass cookstove technologies and kitchen characteristics on indoor air quality and human exposure in rural settings of India. Environ Int [Internet]. 2019;123(November 2018):240-55. Available from:

https://doi.org/10.1016/j.envint.2018.11.059

23. Duguma LA, Minang PA, Freeman OE, Hager H. System wide impacts of fuel usage patterns in the Ethiopian highlands: Potentials for breaking the negative reinforcing feedback cycles. Energy Sustain Dev [Internet]. 2014;20(1):77-85. Available from: http://dx.doi.org/10.1016/j.esd.2014.03.004

24. Zhang J, Smith KR, Ma Y, Ye S, Jiang F, Qi W, et al. Greenhouse gases and other airborne pollutants from household stoves in China: A database for emission factors. Atmos Environ. 2000;34(26):4537-49.

25. Alam SMN, Chowdhury SJ, Begum A, Rahman M. Effect of improved earthen stoves: improving health for rural communities in Bangladesh. Energy Sustain Dev [Internet]. 2006;10(3):46-53. Available from: http://dx.doi.org/10.1016/S0973-0826(08)60543-8

26. Onyeneke RU, Nwajiuba CU, Mmagu CJ, Aligbe JO, Uwadoka CO, Igberi CO, et al. Impact of adoption of improved cook-stove on different components of household welfare in rural communities in Nigeria: The case of Save80 cook-stove in Kaduna. Environ Prog Sustain Energy. 2018;37(4):1327-38.

27. Kapfudzaruwa F, Fay J, Hart T. Improved cookstoves in Africa: Explaining adoption patterns. Dev South Afr [Internet]. 2017;34(5):548-63. Available from: https://doi.org/10.1080/0376835X.2017.1335592

28. Bielecki C, Wingenbach G. Rethinking improved cookstove diffusion programs: A case study of social perceptions and cooking choices in rural Guatemala. Energy Policy [Internet]. 2014;66(2014):350-8. Available from:

http://dx.doi.org/10.1016/j.enpol.2013.10.082

29. Rhodes EL, Dreibelbis R, Klasen E, Naithani N, Baliddawa J, Menya D, et al. Behavioral attitudes and preferences in cooking practices with traditional open-fire stoves in Peru, Nepal, and Kenya: Implications for improved cookstove interventions. Int $\mathrm{J}$ Environ Res Public Health. 2014;11(10):10310-26.

30. Gebreegziabher Z, Mekonnen A, Kassie M, Köhlin G. Urban energy transition and technology adoption: The case of Tigrai, northern Ethiopia. Energy Econ [Internet]. 2012;34(2):410-8. Available from: http://dx.doi.org/10.1016/j.eneco.2011.07.017

31. Smith KR, Dutta K, Chengappa C, Gusain PPS, Berrueta OM and V, Edwards R, et al. Monitoring and evaluation of improved biomass cookstove programs for indoor air quality and stove performance: conclusions from the Household Energy and Health Project [Internet]. Vol. 11, Energy for Sustainable Development. International Energy Initiative, Inc.; 2007. Available from: http://dx.doi.org/10.1016/S0973-0826(08)60396-8

32. Wallmo K, Jacobson SK. A social and environmental evaluation of fuel-efficient cook-stoves and conservation in Uganda. Environ Conserv. 1998;25(2):99-108.

33. Gidey Yirga. Assessment of beekeeping practices in Asgede Tsimbla district, Northern Ethiopia: Absconding, bee forage and bee pests. African J Agric Reseearch. 2012;7(1):1-5. 
34. Bailis R, Berrueta V, Chengappa C, Dutta K, Edwards R, Masera O, et al. Performance testing for monitoring improved biomass stove interventions: experiences of the Household Energy and Health Project This paper is one of six describing work done as part of the Household Energy and Health (HEH) Project. Energy Sustain Dev. 2007;11(2):57-70.

35. GIZ-ECO (Energy Coordination. Mirt Stove Ethiopia. GIZ-ECO Ethiopia, Addis Ababa. Addis Ababa; 2011.

36. UNFCCC. http://cdm.unfccc.int/ProgrammeOfActivities/registered.html. 2013.

37. Fekadu Kedir M, Bekele T, Feleke S. Problems of Mirt, and potentials of improved Gonzie and traditional open cook stoves in biomass consumption and end use emission in rural wooden houses of Southern Ethiopia. Sci African. 2019;3.

38. Gizachew B, Tolera M. Adoption and kitchen performance test of improved cook stove in the Bale Eco-Region of Ethiopia. Energy Sustain Dev [Internet]. 2018;45:186-9. Available from: https://doi.org/10.1016/j.esd.2018.07.002

39. Megen Power Ltd. Final Report: Impact Assessment of Mirt Improved Biomass Injera Stoves [sic] Commercialization in Tigray, Amhara and Oromiya National Regional States, Submitted to the MoARD/GTZ SUN Energy Programme, Addis Ababa. 2008.

40. Johnson MA, Pilco V, Torres R, Joshi S, Shrestha RM, Yagnaraman M, et al. Impacts on household fuel consumption from biomass stove programs in India, Nepal, and Peru. Energy Sustain Dev [Internet]. 2013;17(5):403-11. Available from:

http://dx.doi.org/10.1016/j.esd.2013.04.004

41. Zein-Elabdin EO. Improved stoves in Sub-Saharan Africa: The case of the Sudan. Energy Econ. 1997;19(4):465-75.

42. Tryner J, Willson BD, Marchese AJ. The effects of fuel type and stove design on emissions and efficiency of natural-draft semigasifier biomass cookstoves. Energy Sustain Dev [Internet]. 2014;23(1):99-109. Available from: http://dx.doi.org/10.1016/j.esd.2014.07.009

43. Dissanayake STM, Damte Beyene A, Bluffstone R, Gebreegziabher Z, Kiggundu G, Kooser SH, et al. Improved Biomass Cook Stoves for Climate Change Mitigation? Evidence of Preferences, Willingness to Pay, and Carbon Savings. 2018;(June 2018). Available from: http://www.worldbank.org/research.

\section{Tables}

Table 1: Default parameters used for calculating carbon dioxide emissions using ICS

\begin{tabular}{|lll|}
\hline Parameter & Value & Source \\
\hline Annual wood saving per stove & From KPT & Field survey \\
\hline Net calorific value fuelwood (wet basis) & $15 \mathrm{MJ} / \mathrm{kg}$ & (Hall et al., 1994) \\
\hline Emission factor fuelwood & $112 \mathrm{~g} \cdot \mathrm{CO} / \mathrm{MJ}$ & (IPCC, 2006) \\
\hline Fraction of non-renewable biomass & $88 \%$ & (UNFCC, 2011) \\
\hline
\end{tabular}

Table 2: Age category and experiences of household's stratified by stove type

\begin{tabular}{|c|c|c|c|}
\hline Variables & Mirt $(n=43)$ & TBS $(n=43)$ & Tikikil $(n=53)$ \\
\hline Family size & $5.58 \pm 2.08$ & $6.07 \pm 2.19$ & $3.8 \pm 1.35$ \\
\hline \multicolumn{4}{|l|}{ List of gender and age } \\
\hline Children: 0-14 & $2.40 \pm 1.64$ & $2.28 \pm 1.53$ & $1.76 \pm 1.19$ \\
\hline Females: > 14 & $1.63 \pm 1.02$ & $1.88 \pm 1.07$ & $1.08 \pm 0.94$ \\
\hline Males: 15 - 59 & $1.35 \pm 1.02$ & $1.63 \pm 1.13$ & $0.94 \pm 0.46$ \\
\hline Males: $>59$ & $0.21 \pm 0.46$ & $0.28 \pm 0.45$ & $0.06 \pm 0.23$ \\
\hline
\end{tabular}

TBS stands for traditional baking stove 
Table 3: Average total wood consumption of HHs using improved Stove ("Mirt") and traditional baking stove (TBS)

\begin{tabular}{|llllll|}
\hline $\begin{array}{l}\text { Stove } \\
\text { type }\end{array}$ & $\begin{array}{l}\text { No. of adult } \\
\text { equivalent }\end{array}$ & $\begin{array}{l}\text { Wet wood used } \\
\text { (kg/2days) }\end{array}$ & $\begin{array}{l}\text { Wet wood used per capita } \\
\text { (kg/2days) }\end{array}$ & $\begin{array}{l}\text { Dry wood used } \\
\text { (kg/2days) }\end{array}$ & $\begin{array}{l}\text { Dry wood used per capita } \\
(\mathrm{kg} / 2 \text { days })\end{array}$ \\
\hline Mirt & $3.73 \pm 1.55$ & $4.52 \pm 2.87$ & $1.32 \pm 0.92$ & $4.49 \pm 2.83$ & $1.32 \pm 0.92$ \\
\hline TBS & $4.54 \pm 1.88$ & $6.92 \pm 2.35$ & $1.69 \pm 0.65$ & $6.83 \pm 2.33$ & $1.67 \pm 0.66$ \\
\hline $\begin{array}{l}\text { p- } \\
\text { value }\end{array}$ & 0.033 & 0.000 & 0.039 & 0.000 & 0.047 \\
\hline
\end{tabular}

Table 4: Average total wood consumption of Asgede Tsimbla HHs using improved Stove ("Tikikil") and traditional cooking stove (TCS)

\begin{tabular}{|llllll|}
\hline $\begin{array}{l}\text { Stove } \\
\text { type }\end{array}$ & $\begin{array}{l}\text { No. of adult } \\
\text { equivalent }\end{array}$ & $\begin{array}{l}\text { Wet wood used } \\
(\mathrm{kg} / \text { day })\end{array}$ & $\begin{array}{l}\text { Wet wood used per capita } \\
(\mathrm{kg} / \text { day })\end{array}$ & $\begin{array}{l}\text { Dry wood used } \\
(\mathrm{kg} / \text { day })\end{array}$ & $\begin{array}{l}\text { Dry wood used per capita } \\
(\mathrm{kg} / \mathrm{day})\end{array}$ \\
\hline Tikikil & $3.22 \pm 1.05$ & $2.29 \pm 0.74$ & $0.82 \pm 0.57$ & $2.29 \pm 0.74$ & $0.82 \pm 0.57$ \\
\hline TCS & $3.34 \pm 0.98$ & $2.80 \pm 0.77$ & $0.94 \pm 0.52$ & $2.80 \pm 0.78$ & $0.97 \pm 0.51$ \\
\hline P-value & 0.778 & 0.000 & 0.002 & 0.000 & 0.002 \\
\hline
\end{tabular}

\section{Figures}

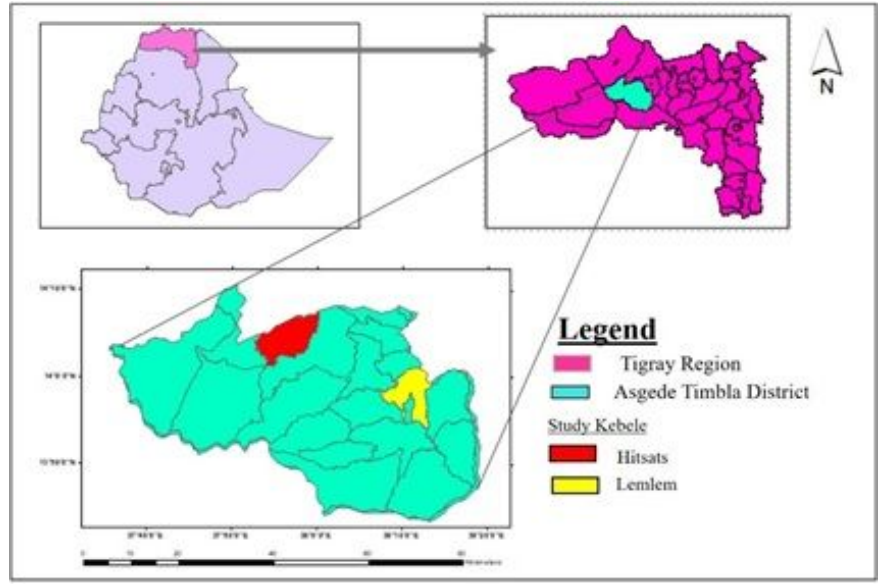

Figure 1

Study sites
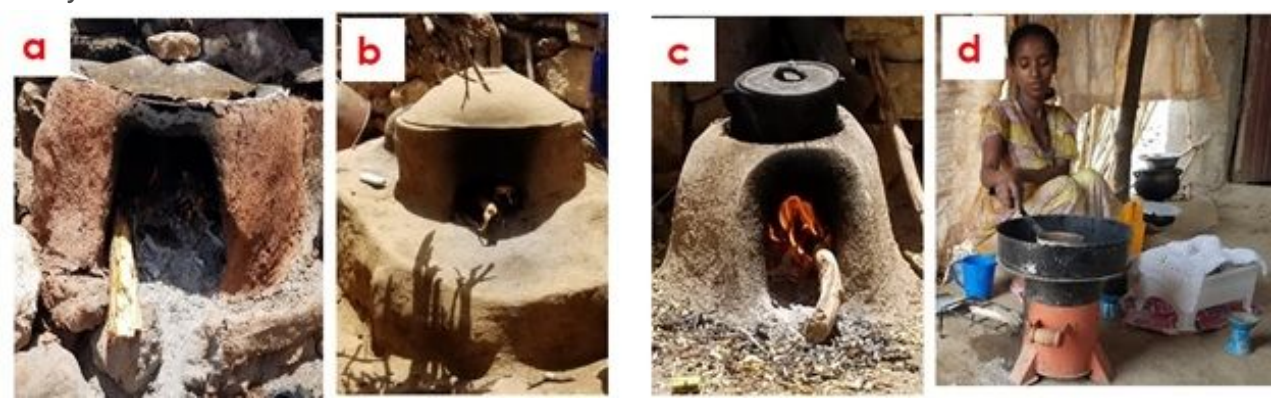

Figure 2 
(a) Traditional baking stove, (b) improved baking stove ("Mirt"), (C) Traditional cooking stove and (D) improved cooking stove ("Tikikil") used in Asgede Tsimbla Districts
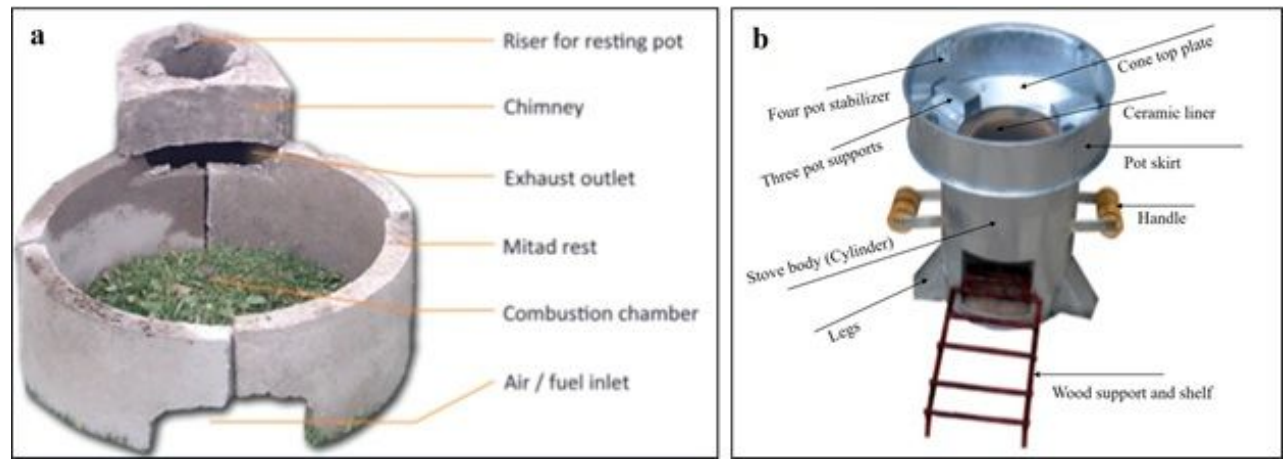

\section{Figure 3}

The different parts of improved a= "Mirt" and b = "Tikikil Gonzie stove (Dresen et al., 2014; GIZ-ECO, 2011)

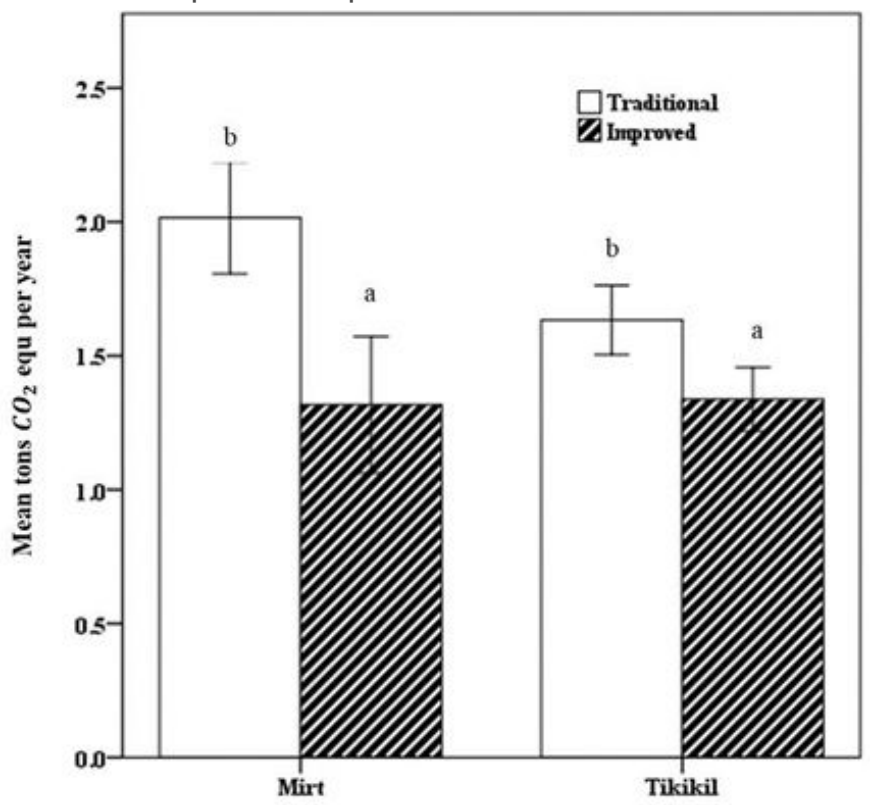

Figure 4

Valuation of Carbon emission from traditional and improved stoves. Different letters indicate significant differences $(p<0.05)$ 